\title{
The Efforts of Islamic Criminal Law Integration into Indonesian Law Procedures
}

\author{
Muhammad Arifin \\ University of Muhammmadiyah Sumatera Utara, Medan, Indonesia \\ muharifingultom@umsu.ac.id
}

\begin{abstract}
In recent years, there have been widespread criminal cases with enormous intensity. With a variety of modus operandi, criminal cases both committed by individuals and collectives, are carried out by ordinary people to the executive, legislative and also the judiciary. The cases that most render the sense of justice ripped apart are the many cases of corruption, bribery and collusion. The judiciary that is trusted often betrays a sense of justice by only giving very light laws for cases of corruption and bribery which are detrimental to the country's finances. Therefore many people, especially Muslims, want the application of Islamic law in the criminal field. With strict legal sanctions and supported by sources that originate from the Qur'an, it is hoped that the existing crime can be minimized.
\end{abstract}

\section{Keywords}

integration; Islamic crime;

legal system; Indonesia

\section{Introduction}

The rise of criminal acts in the past few years after the reforms in mid-1998 led to an analysis that the criminal law in force today was apparently not enough to minimize the impact of crime. Cases of murder, robbery, attempts to secede from the Republic of Indonesia, abortion, free sex, and the biggest are cases of corruption, more and more occur.

The state in this case is apparently unable to guarantee safety for its people. This means that in legal cases, the State is not present when the people need protection from any existing crime. Therefore, various opinions emerged for the need for Indonesia to abandon the system that is used today, then move on to Islamic law which is far more perfect.

The desire was initiated by some Muslims who wanted the Jakarta Charter to provide an opportunity for Muslims to practice their religious sharia again. They consider that the destruction of the nation today is mainly due to the legal system of the Indonesian people which is not rooted in the aspirations that live in its society, the majority of which embrace Islam.

For criminal cases in corruption cases, for example, the Indonesian people are fed up with various existing cases. Not that there are fewer and fewer cases, each year it even increases. This is also the case with bribery, collusion and others. The legal sanctions imposed were apparently unable to deter white-collar criminals.

Based on the back ground of the various facts and realities available, then there is a solution to reduce these crimes, namely by applying the Islamic criminal law system, which is strict not hard nor cruel. With the basis of a sacred source with no doubt about its authenticity, it is expected to be able to provide a sense of justice for justice seekers who live in this republic.

This paper tries to provide a thought idea that is constructive for legal revival in Indonesia. 


\section{Review of Literature}

\section{The Meaning of Islamic Law and Islamic Criminal Law}

There are several terms that will definitely appear when talking about Islamic law, namely sharia, fiqh, qanun, fatwa, qadha, siyasa syar'iyah and law.

Islamic law is essentially a law that originates and becomes part of the Islamic religion. The word Islamic law is actually not found at all in the Qur'an, but what is in the Qur'an is the word sharia, jurisprudence, law and the same root. According to records in Western literature, Islamic law is a translation of the term "Islamic Law". Given the importance of this terminology, every person and group tends to understand it in accordance with their respective frameworks.

According to Usammah (2019) Islamic Shari'ais a perfect guide as a medium for the mankind in fulfilling its obligations to God. IslamicShari'awhich is revealed by Allah is aShari'athat fulfills the justice of the mankind, upholds honesty, provides broad benefit for the legal problems of the community, as well as Shari'ah is far from tyranny and certain interests in all laws. As a product of perfect legislation and no one party is able to create or make rules or legislation as complete, as perfect as the Islamic Shari'arevealed by Allah SWT.

The word Islamic law itself, summarizes some of the meanings in the treasures of Islamic sciences. Islamic law is sometimes also understood as sharia. The word shari'a or shari'ah means the path that leads to a well-traveled spring. Sharia etymologically means the path through which water is drained, or where river water passes. This word was then connoted by the Arabs with "the straight path that must be headed". Still etymologically, sharia means al-'utbah (valley curves), al-'atabah (doorway and stairs), maurid ash-sharibah (the path where the drinker looks for water) and ath-thariqah al-mustaqimah (the straight path). Meaning practically, sharia means road, customs, regulations, laws, laws.

The term Shari'a is also used in everyday terms as a spring which is always taken for their living needs. Sharia word forms in the Qur'an can be found in five verses, namely Q.S. Almaidah verse 48 (syir'ah), Q.S. Aljasiyah verse 18 (syariah), Q.S. Al'araf verse 163 (syurra'a), and Q.S. Alsyura verses 13 and 21 (syara'a, syara'u).

Islamic jurists are not uniform in defining what sharia is. Some say that the Shari'a is a form of God's laws which are appreciated from the Qur'an and Hadith. Some other Islamic jurists position the Shari'ah parallel to the Aqeedah. That is, the Shari'a and creed are placed in a complementary perspective, complementing each other with unequal cultivated areas.

According to the terminology, according to the ijma' of the ulema, the Shari'a is:

"The laws of Allah which were instituted by God for His servants, brought by one of His Prophets, both of these laws relate to the way of carrying out the actions that are called" branch deeds laws ", and for him the science of jurisprudence is gathered or related to the way of holding trust (i'tikad), which is called the "main laws" and beliefs, and for it the knowledge of kalam is collected. Shari'at is also called Religion (al-din and millah)".

Abdullah Yusuf Ali translates the word Shari'a as the right way of religion which is broader than formal worship and legal verses revealed to the Prophet Muhammad. Rifyal Ka'bah understands Shari'a as Divine law with the understanding that it is a concrete manifestation of Divine will through human obedience to follow His guidance in personal life and the life of the people.

The concept of Shari'a given by the two Islamic jurists above seems to contain two meanings namely general understanding and special understanding. Sharia in general terms is the overall order of life in Islam, including knowledge of God. Sharia in this definition is 
often referred to as fiqh Akbar. Sharia in a special sense connotes fiqh or often referred to as fiqh ashghar, namely the legal provisions resulting from the understanding of Muslims who meet certain requirements about the Qur'an and Sunnah by using certain methods (ushul fqih). Based on the understanding of these terms, the term 'tasyri' or 'tasyri' al-Islamy is formed which means the laws and regulations are arranged in accordance with the foundations and principles contained in the Qur'an and Sunnah.

Nur A. Fadhil Lubis said that the word shari'a itself as the Bible of God related to the act of the mukallaf (subject of law). The term sharia actually has a broad meaning, not only in terms of fiqh and law, but also includes creeds and morals. Thus the sharia means meaning of realizing Allah, obeying Him, believing in His apostles, His books and the day of vengeance. In short, sharia includes everything that brings a person to surrender to God (Muslim).

According to Manna 'al-Qaththan, Shari'a is all the provisions of Allah that are prescribed to His servants both in terms of creed, morals or muamalah. The term sharia in the context of the study of Islamic law further describes the set of legal norms that are the result of the tasyri process. The word tasyri 'is a mashdar form of syarra' which means to create and establish sharia. In the terms of the ulama ushul fiqh of sharia it means establishing legal norms to organize human life both in relation to God, and with other human beings.

Therefore, what is meant by sharia is a regulation that has been established (revealed) by Allah to the Prophet Muhammad, for humans which includes three fields, namely the fields of beliefs, deeds, and morals. Wilfred Cantwell Smith said that sharia is the essence of law in Islam as an elaboration of God's commands. In general, sharia is a rule or laws (religion) that have been revealed by Allah, to His servants through the Prophet Muhammad, both in the form of the Qur'an and Hadith which includes areas of monotheism, kalam, tasawuf, and fiqh.

Islamic law can also be interpreted as fiqh. Jurisprudence is defined by a collection of syariah laws' (relating to) the actions / actions taken from their specific arguments. Qodri Azizi said that jurisprudence could be called Islamic jurisprudence (Islamic Jurisprudence), but in it also obtained legal material and even legal procedures in court proceedings (procedural law / fiqh al-murafa'at).

Fiqh is knowledge that is produced by the mind and ijtihad (research) and requires thought and reflection. Therefore God cannot be called faqih (expert in fiqh), because for Him there is nothing unclear.

Islamic criminal law in the terminology of Islamic law is known as jinayah fiqh. Basically the terminology definition of the term jinayah refers to the results of one's actions. Normally this definition is bound to prohibited acts. In the jurists, the jinayah means forbidden acts according to shariah. However, in general the jurists use the terminology only for actions that threaten life safety such as beatings, murder and so on.

\section{Discussion}

\subsection{Islamic Law in Positive Law in Indonesia}

Islamic law as a legal order that is guided and obeyed by the majority of the population and the people of Indonesia is a law that has lived in society, and is a part of Islamic teachings and beliefs that exist in national life, and is an ingredient in their development and development.

The historical facts of the journey of law in Indonesia describe that the presence of Islamic law in national law is a struggle for existence. The theory of existence formulates the state of Indonesia's national law past, present, and future, asserting that Islamic law exists in Indonesian national law, both written and unwritten. 
Islamic law as a legal order that is guided and obeyed by the majority of the population and the people of Indonesia is a law that has lived in society, and is part of Islamic teachings and beliefs that exist in the life of national law, and is an ingredient in their coaching and development In the Indonesian context, the existence of Islamic law at the applicative level becomes positive law (ius constituendum) only relating to private law, namely ubudiah and muamalah. While those relating to Islamic public law to this day are still the law aspired. It is ironic if seen from any aspect, that something which is public in nature is actually not legalized but which is related to private matters is precisely made into positive law.

According to TAP MPR number III / MPR / 2000 the source of national basic law is Pancasila, while the order of the laws and regulations is:

a. The 1945 Constitution which is the written basic source of the Republic of Indonesia and contains the basis and outline of law in the administration of the State. The original 1945 law which was considered sacred since 19 October 1999 has been amended 4 times.

b. Decree of the People's Consultative Assembly.

c. The law was made by the House of Representatives and the President to implement the 1945 Constitution and the provisions of the People's Consultative Assembly.

d. Government regulations in lieu of laws made by the President in terms of matters of concern with conditions submitted to the Parliament.

e. Presidential Decrees which are set and made by the President to carry out their functions and duties in the form of arrangements for the implementation of state administration and government administration.

f. Regional Regulations that accommodate the special conditions of their regions made by the Provincial DPRD and the Governor, Regent and Regency / City DPRD, village regulations whose procedures for formation are regulated in their respective Regional Regulations.

Philosophically, the source of national law comes from three laws that exist in Indonesia: Customary law, Western law and Islamic law, which are also used as a source of law. Islamic law has actually been in effect since the entry of Islam in Indonesia. Islamic law in subsequent developments was made as one of the basic ingredients of national law besides customary law and Western law.

Islamic law is in national law, seen in various statutory regulations in various fields of law. It appears that Islamic law exists and is obeyed even though it is still an unwritten law. Also seen is the tradition of Indonesian constitutionality that prioritizes religious law and religious teachings that are authoritative in the practice of Indonesian state administration.

This is in accordance with the theory of existence which states that the existence of Islamic law in Indonesian National Law. This theory also reveals that the form of the existence of Islamic law in Indonesian national law is:

1. There is in a sense, it is with its independence that is recognized for its existence and strength and authority by national law and given the status of national law

2. There is in national law, in the sense that Islamic legal norms function as filters for Indonesian national legal materials

3. There is in a meaning, as the main ingredient and the main element of Indonesian national law.

Based on the description above obtained a complete description of the position of Islamic law in Indonesian law now is:

1. Islamic law referred to and determined by statutory regulations can apply directly without having to go through customary law.

2. The Republic of Indonesia is obliged to regulate something in accordance with Islamic law, as long as the regulation only applies to Muslims. 
3. The position of Islamic law in the Indonesian legal system is equal and on par with customary law and Western law.

4. Islamic law is also a source of the formation of national law that will come, in addition to customary law, Western law and other laws that grow and develop in the Republic of Indonesia.

\subsection{The Integration of Islamic Criminal Law into Indonesian Law}

\section{a. Islamic Views of Islamic Law Enforcement}

Among Muslim scholars there are still differences in responding to the idea of formalizing Islamic law in Indonesia. There are those who agree, but not a few who reject it. Din Syamsuddin said that there were three forms of Islamic appearances in Indonesia, especially after the new order until now, namely:

1) Formalistic

2) Substantiality

3) Fundamentalists.

Form of application formally according to Deliar Noer needs to be supported and carried out by the state. Noer agreed with Ahmad Syaf'i Ma'arif's view that Islam entered through a long acculturation process with the local culture. But on the way, local culture that is contrary to Islam increasingly marginalized. Therefore, Islam is actually an inseparable part of people's lives. So, it is natural that the application of Islamic law needs to be formalized and carried out by the state.

Unlike Deliar Noer, Nurcholis Madjid rejects the formalization of Islamic law in Indonesia. Cak Nur, the nickname of Nurcholis Madjid, said that the steps or efforts to formalize Islamic Sharia were not a priority. According to Cak Nur, Islam must be defined inclusively. With this interpretation, the symbols of Islam must be open and able to be understood by all Muslims. This does not mean that Muslims must renounce the ideals of Islam and compromise at the expense of Islamic principles. To that end, Cak Nur stressed the importance of Muslims ending the exclusive image of Islam-oriented politics and sacrificing short-term political results for more meaningful long-term results.

Cak Nur saw that the amendment of the 1945 Constitution and efforts to re-enter the Jakarta Charter were the attitudes and tendencies of Muslims who still see everything in a formalistic and symbolic perspective. This finally, according to Cak Nur brought an exclusive attitude in religion. For the third appearance, namely fundamentalist Islam, it will appear in recent years, there are a handful of groups of Muslims who want to lift the foundations of Islam into the current political reality.

The emergence of Islamic fundamentalism in Indonesia is partly influenced by international factors, namely the development of Islamic fundamentalism in the international world, and also nationally, namely by the internal dialectical dynamics in Indonesian Islamic politics itself. The birth of Islamic fundamentalism in Indonesia is due to the fact that the two forms of the appearance of Indonesian Islam as described above have failed to make Islam as a medium of Indonesia's political balance in filling the developing political system.

The emergence of Islamic fundamentalism is not without apparent reason. They consider that only by implementing Islamic sharia, Indonesia will be able to get out of various crises, especially economic, legal and moral crises. However, the path used by most Islamic fundamentalism movements in Indonesia is using the method of violence.

\section{b. The Marginalization of Islamic Criminal Law in Indonesia}

When looking at aspects of Islamic law from the point of view of being muamalah, it has been posited in Indonesian law, not so with criminal law. Although various parties have 
offered many criminal laws with Islamic nuances (as academic designs), the government has yet to fully respond to them. The perfection of Islamic law in a kaffah (perfect), precisely just one step away, namely the application of criminal law for Muslims who commit violations or crime. Therefore, in fact Islamic criminal law is very much needed and will guarantee the peace of the whole community. The formulation of the subject of corruption as regulated in Article 7 can be interpreted that in its understanding includes the corporation as the culprit. The existence of the word "contractor" can be interpreted as a human being or also a corporation, because the work mentioned in the article can be done by humans or by corporations (Gunawan, 2019).

However, many reject the implementation of Islamic criminal law in Indonesia. Ironically, that rejection is precisely done by many people who are Muslims themselves. With a variety of reasons, thoughts, ideas, and propositions, they are very allergic to everything that smells of Islam. According to Yahya Harahap, things like the above can occur due to experts and legal experts as well as figures who have positions and important roles in making policies in state affairs and also formulating and formulating national law, which if most claim to be Muslim, most of them mentally and have an accidental outlook.

Various efforts both transformation, psotification and institutionalization of Islamic law in Indonesia always meet a very steep stumbling block. Various legal products, regional regulations (Perda) are directed not to use Islamic law as the source. Whereas theoretically, the existence of law that lives in society can be understood as respect for the values and rules of rules that are known, implemented and obeyed so that it becomes a symbol in a society.

However, to this day Islamic law is still in the form of norms which contain prohibitions and orders that must be considered in the association of life, not yet a legal norm. Such norms can become official law recognized by the state and binding if they have been positivated through state institutions. Various transformation efforts, the positification of Islamic law certainly cannot be separated from the political aspects of law which are a series of strong links to make improvements to law in people's lives. However, in parliament there was also a struggle, a conversion process to change an in put (legal need) into an out put (legal product) in a black box.

As a result, instead of promoting and institutionalizing Islamic law via political institutions, this effort was counterproductive politically, related to the existence of Islamophobia originating from the remnants of the Crusades and also the historical struggle of Islamic nationalism with nationalists in the past constituent era is a legacy of the theory of reception belongs to Snouck Hurgronje. Speaking not optimally and the slow pace of Islamic criminal law integrated into the legal system in Indonesia, it is better to know in full some of the obstacles in the effort to enforce and enforce Islamic criminal law in Indonesia. Topo Santoso said there were several obstacles encountered in the context of integrating Islamic criminal law into Indonesian legal system:

1) Cultural or sociological constraints, namely the existence of Muslims who cannot yet accept;

2) Thinking (fikrah) constraints, namely the number of negative views on Islamic criminal law and not sure of their effectiveness;

3) Hilosophical constraints in the form of accusations that this law is unfair and cruel and out of date and contradicts the ideals of national law;

4) Juridical constraints that are reflected in the absence of criminal law provisions that originate from Islamic sharia;

5) Consolidation constraints, namely the lack of support for the adoption of Islamic shari'a (from various circles) which still emphasizes the arguments and methods of their implementation; 
6) Academic constraints, seen from the not yet widespread teaching of Islamic criminal law in schools or campuses;

7) Constraints of formulation that can be seen from the absence of systematic efforts to formulate criminal law in accordance with Islamic sharia as preparation to replace Western criminal law;

8) Structural constraints that can be seen from the absence of a legal structure that can support the application of Islamic sharia;

9) Scientific constraints, reflected in the lack of scientific literature that reviews Islamic criminal law; and

10) Political constraints, seen from insufficient political power to pass the application of Islamic law through the political process.

Other constraints encountered regarding the integration of Islamic law into the Indonesian legal system are:

1. National diversity. Indonesia is a country that has a very wide area, each of which has its own social and cultural conditions so that it is not easy to approach each other.

2. Legal education methods. During this time, law studies taught to students are trichotomies between Western law, Islamic law and customary law. Since Indonesian society is relatively heterogeneous and its territory is quite extensive, it will increasingly result in finding common ground between these legal elements. So, what is needed now is an integral understanding of legal experts from the three legal sources. That certainly requires a very heavy intellectual struggle. Islamic education is a process to create a whole person of faith and piety to God and be able to realize his existence as the caliph of Allah SWT on earth based on Al-Qu'ran and Sunnah. Islamic education is also a physical-spiritual guidance based on Islamic religious laws leading to the formation of a main personality according to Islamic standards (Muktar, 2019).

3. Lack of academic study in the field of Islamic law. The lag in developing Islamic study centers is caused by:

a. Historically, centers of study that did not respect Islamic law that developed earlier did not provide a place for the study of Islamic law;

b. The study of Islamic law lies between the study of religion and the study of jurisprudence, consequently the aspects of the study are not exhaustive;

c. The development of the quality of Islamic obedience that is weak, especially beliefs and moral beliefs that are difficult to control resulting in a decrease in moral quality in the implementation of law;

d. Still adheres to the Dutch political law policy which has its own political interests, for example Muslims may not submit to their own religious laws, and the religious independence of the Judicial Court is not yet fully involved in civil disputes except family law;

e. Many problems faced by Muslims, while there is no legal fatwa that can summarize them in a single legislation that can be accepted by all elements of Islamic society.

Hamka Haq detects there are at least three things why Islamic criminal law cannot be formally applied textually on Indonesian soil, viz

1. That the sanctions specified in the text of the Qur'an and some of the traditions can no longer apply as they are due to the times. For example, one of the sanctions for the perpetrators of unintentional killings or perpetrators of pledge / perjury is to free slaves. This sanction is impossible to enforce in modern civilization that no longer knows slavery today.

2. In the era of globalization and plural there is an opportunity to convert, so that a Muslim criminal can be free from the bondage of Islamic criminal law by changing religions. 
Conversion is a human right guaranteed by international law, so that the person concerned is automatically free from the punishment of jinayah.

3. As a unitary state, the Indonesian constitution does not want a criminal law that applies unilaterally to Muslims, while other communities reject it.

During this misunderstanding Indonesia understands the Islamic criminal law caused by excessive fear, especially for non-Muslim communities and also Muslims themselves. In a country that embraces pluralism, Islamic criminal law does not apply to non-Muslims.

Referring to Muhammad Qutb's book, Islam the Misunderstood Religion, 'Islam of Misunderstood Religion', it is not clear that Islamic law also becomes 'misunderstood law'. So for Islamic criminal law the misunderstanding and attack is even more intense.

A lot of research has been done to find out the superiority of Islamic criminal law at the applicative level. Empirical evidence shows that the implementation of Islamic criminal law in Saudi Arabia is able to reduce crime rates to a very low point. Freda Adler, a professor from the United States, listed Saudi Arabia as one of the ten countries with the predicate "countries with the lowest crime rates. According to Souryal, as quoted by Topo Santoso, said that Islamic law plays a very important role in shaping an anti-crime society and a society with high social control.

\section{Conclusion}

Many constraints are faced when discourse or efforts to integrate Islamic criminal law into Indonesian law system. The constraints are on the internal side of the Muslim community itself as well as from external aspects. The road in that direction might still be too long. However, if the public knows what the positive effects of the implementation of Islamic criminal law are, it is very likely that they will actually be shouting the enforcement of Islamic criminal law.

The majority of ordinary people only look at from the aspect of law sanctions without looking at the philosophical, sociological substance of Islamic criminal law. Society never wants to open its eyes to see how beautiful and elegant Islamic law protects every living human right. Then the biggest constraint is the existence of psychiatric illness that envelops many people about fear of anything that smells of Islam, known as Islamophobia.

\section{References}

'Alim, Yusuf Hamid al-. 1994. al-Maqashid al-'Ammah li al-Syari'ah al-Islamiyyah. Riyadh: Dar al-'Ilmiyyah li al-Kitab al-Islamy.

A. Djazuli. 1997. Fiqh Jinayah (Upaya Penanggulangan Kejahatan dalam Islam). Jakarta: PT. RajaGrafindo Persada, Cet. Ke-2.

A. Rahmat Rosyadi dan M. Rais Rahmat. 2006. Formalisasi Syariat Islam dalam Perspektif Tata Hukum Indonesia. Bogor: Penerbit Ghalia Indonesia.

A.Qodri Azizi. 2002. Eklektisisme Hukum Nasional: Kompetisi Antara Hukum Islam dan Hukum Umum). Yogyakarta: Gama Media.

Abu Yasid. 2007. Nalar \& Wahyu Interrelasi dalam Proses Pembentukan Syari'at, Jakarta: Penerbit Erlangga.

Adler, Freda , Mueller dan William S. Laufer. 1991. Criminology . New York: Mc Graw Hill. Ahmad Hanafi. 1989.Pengantar dan Sejarah Hukum Islam, Jakarta: Bulan Bintang.

Ahmad Taqwim. 2009. Hukum Islam Dalam Perspektif Pemikiran Rasional, Tradisional, dan Fundamental. Semarang: Walisongo Press.

Ahmad Warson Munawwir.1997. Kamus Al-Munawwir, Surabaya: Pustaka Progressif 
Ali, Abdullah Yusuf. 1989. The Holy al-Qur'an: Text, Translation and Commentary. Amryland: Amana Corporation.

Dedi Supriyadi. 2007. Sejarah Hukum Islam (Dari Kawasan Jazirah Arab sampai Indonesia), Bandung: CV. Pustaka Setia.

Dhurayh, Sa'ud ibn Sa'ad 'Ali. 1973. Al-Tanzhim al-Qadha'i fi al-Mamlakah al-'Arabiyah. Riyadh: Matabi' Hanifah li al-Ubset.

Esmi Wrassih. 2005. Pranata Hukum Sebuah Telaah Sosiologis. Semarang: Suryandaru.

Fathurrahman Djamil. 1999. Filsafat Hukum Islam, Jakarta: Logos.

Fazlurrahman. 1979. Islam. Chicago-London: Universitiy of Chicago Press.

Gunawan and Syahrin (2019). Demand against Law and Using Authority in Corruption Criminal Action. Budapest International Research and Critics Institute (BIRCIJournal): Humanities and Social Sciences, 194-206.

Hamka Haq. 2009. Islam Rahmah Untuk Bangsa. Jakarat: RMBOOKS.

Ichtijanto. "Pengembangan Teori Berlakunya Hukum Islam Di Indonesia", dalam Juhaya S. Praja. 1991. Hukum Islam Di Indonesia, Perkembangan Dan Pembentukan. Bandung: PT. Remaja Rosdakarya.

Ismail, Sya'ban Muhammad. 1985 al-Tasyri' al-Islamy: Mashadiruh wa ath-Waruh, Mesir: Maktabah al-Nahdhah al-Misriyyah.

Khallaf, Abd al-Wahhab. 1978. 'Ilm Ushul al-Fiqh. Kuwait: Dar al-Qalam.

M. Din Syamsuddin. 2001. Islam danPolitik Orede Baru. Jakarta: PT Logos Wacana Ilmu.

Ma'luf, Louis. 1986. al-Munjid fi al-Lughah, Beirut: Dar al-Masyriq.

Makhrus Munajat. 2004. Dekonstruksi Hukum Pidana Islam. Sleman: Logung Pustaka.

Mardani. 2009. Hukum Acara Perdata Peradilan Agama \& Mahkamah Syar'iyah. Jakarta: Sinar Grafika.

. 2010. Hukum Islam Pengantar Ilmu Hukum Islam di Indonesia. Yogyakarta: Pustaka Pelajar.

Mishry, Ibn Manzur al-Afriqy al-. 1956. Lisan al-'Arab. t.t.p: Dar al-Shadr li al-Thaba'ah wa al-Nasyr, Jilid 10.

Mohammad Daud Ali. 1996. Hukum Islam Pengantar Ilmu Hukum dan Tata Hukum Islam di Indonesia. Jakarta: Rajawali Pers.

Muhammad Iqbal. 2004. "Penerapan Syariat Islam Di Indonesia", dalam Syariat Islam di Indonesia Aktualisasi Ajaran dalam Dimensi Ekonomi, Politik, dan Hukum._Editor Muhammad Iqbal, Azhari Akmal Tarigan. Jakarta- Medan: Diterbitkan atas kerja sama Fakultas Syariah IAIN Sumatera Utara dengan Penerbit Misaka Galiza.

Muktar, et al. (2019). Existence of Pranatal Education in Islam. Britain International of Linguistics, Arts and Education (BIoLAE) Journal, 210-223

Muqaddas, Al-Khusni al-. t.t. Fathu Ar-Rahman, Indonesia: Maktabah Dahlan.

Musa, Kamil, 1989. al-Madkhal ila al-Tasyri' al-Islamy, Beirut: Mu'assasah al-Risalah.

Muslehuddin, Muhammad. t.t. Philosophy of Islamic Law and the Orientalist, Lahore: Islamic Publication L.T.D., Shah Alam Market.

Nabhan, Muhammad Faruq.1981. al-Madkhal li al-Tasyri' al-Islamy, Beirut: Dar al-Qalam.

Nur A. Fadhil Lubis. 1995. Hukum Islam dalam Kerangka Fiqh dan Tatanan Hukum Indonesia. Medan : IAIN Press.

Nurcholis Madjid, "Tak Usah Membuka Kotak Pandora”, dalam Ahmad Syafi'i Ma'arif, et.al. 2001. Syari'at Islam Yes Syari'at Islam No. Jakarta: Paramadina.

. 1987. Islam Kemodernan dan Keindonesiaan. Bandung: Mizan.

Pagar, "Kontribusi Islam Dalam Pembangunan Hukum Nasional", dalam Fuji Rahmadi (editor). 2009. Pembaharuan Hukum Islam Di Indonesia Menggugat Kemapanan Tradisionalisme. Bandung: Citapustaka Media Perintis. 
Ratno Lukito. 1998. Pergumulan Hukum Islam dan Adat di Indonesia. Jakarta: INIS.

Rifyal Ka'bah. 1999. Hukum Islam di Indonesia. Jakarta: Universitas Yarsi.

Samsul Bahri. 2007. Membumikan Syari'at Islam Strategi Positivikasi Hukum Islam Melalui Yurisprudensi Mahkamah Agung. Semarang: Pustaka Rizki Putra.

Schacht, Joseph. 1985. Pengantar Hukum Islam, Jakarta: Dirjen Binbaga Islam Departemen Agama RI.

Smith, Wilfred Cantwell. 1965. Islam in Modern History, New Jersey: Princeton University Press.

Sudikno Mertokusumo. 2003. Mengenal Hukum; Suatu Pengantar. Yogyakarta: Liberty.

Syafriadi Saragih, "Marginalisasi Hukum Pidana Islam Di Indonesia", dalam Fuji Rahmadi. 2009. Pembaharuan Hukum Islam Di Indonesia. Bandung: Citapustaka Media.

Usamah. (2019). akzir as a Punishment in Islamic Criminal Law (Study of the Establishment of Punishment in Criminal Acts in Qanun). Britain International of Humanties and Social Sciences (BIoHS) Journal, 100-108.

Topo Santoso. 2003. Membumikan Hukum Pidana Islam Penegakan Syariat Dalam Wacana Dan Agenda. Jakarta: Gema Insani Press.

Yahya Harahap. 1990. Kedudukan Kewenangan Dan Acara Peradilan Agama, UndangUndang No. 7 Tahun 1989. Jakarta: Pustaka Kartini.

Zainuddin Ali. 2008. Hukum Islam Pengantar Ilmu Hukum Islam di Indonesia, Jakarta: Sinar Grafika, Cet. Ke-2.

Nur A. Fadhil Lubis. Transformasi Hukum Islam Di Indonesia Suatu Refleksi. Makalah disampaikan dalam Seminar Refleksi 50 Tahun Indonesia Merdeka yang Diselenggarakan Senat Mahasiswa Fakultas Syari'ah IAIN Sumatera Utara Medan tanggal 14 Oktober 1995.

Nurul Hakim, "Upaya Transformasi Hukum Islam Kedalam Tata Hukum Indonesia", dalam Jurnal Intiqad, Volume 3 Nomor 1 Juni 2010.

Rifyal Ka'bah, "Reformasi Pembangunan Metodologi Hukum Islam", dalam Mimbar Hukum, No. 43. Jakarta: Yayasan Al-Hikmah, 1999.

Syafruddin Syam, "Sistem Hukum Islam dalam Kerangka Hukum Positif (Survei terhadap Lembaga Mahkamah Syar'iyah di Aceh)", dalam Jurnal Doktrin, Vol. I. Nomor 1, Januari- Juni 2010. 